\title{
Coördinatie in complexe systemen: het ontstaan van stuurloosheid in het Nederlandse spoorwegsysteem
}

\author{
D. (Danny) Schipper ${ }^{1}$, J.F.M. (Joop) Koppenjan² \& L. (Lasse) Gerrits ${ }^{3}$ \\ 1,2 Bestuurskunde, Erasmus Universiteit Rotterdam, Nederland \\ E-mail: schipper@fsw.eur.nl \\ E-Mail: koppenjan@fsw.eur.nl \\ ${ }^{3}$ Politieke Wetenschappen, Otto-Friedrich Universiteit Bamberg, Duitsland \\ E-mail: lasse.gerrits@uni-bamberg.de
}

\begin{abstract}
Gepubliceerd als:
D.Schipper, L. Gerrits en J.F.M. Koppenjan (2015) , Coördinatie in complexe systemen: het ontstaan van stuurloosheid in het Nederlandse spoorwegsysteem, in Bestuurskunde (24)3, pp. 32-44.
\end{abstract}

We zijn ons pas bewust van onze afhankelijk van grote infrastructurele systemen op momenten dat deze het af laten weten. Tegelijkertijd zijn deze systemen door privatisering en verzelfstandiging steeds meer gefragmenteerd geraakt. In dit artikel willen wij inzicht geven in de complexiteit van het Nederlandse spoorsysteem en duidelijk maken waarom het in een dergelijk systeem zo moeilijk is om calamiteiten te voorkomen. Dit doen wij middels een reconstructie van de buitengebruikname van wissels en sporen op 19 februari 2014. Op deze dag raakte het proces van buitengebruikname stuurloos, met als gevolg dat het treinverkeer rond Den Haag abrupt stil kwam te liggen. Aan de hand van het begrip sensemaking laten wij zien waarom de verschillende betrokkenen in het spoorsysteem er niet in slaagden om tot een gezamenlijke beeldvorming te komen en een gecoördineerde afschaling van de treindienst onmogelijk werd.

\section{Coordination in complex systems: the loss of a common ground in the Dutch railway system}

We are only fully aware of our dependency on large scale technical infrastructure systems when they fail to provide reliable services. Yet, at the same time we have witnessed the dismantling of the organizations providing these services due to privatization and liberalization policies. In this article we provide insight into the complexity of managing these now networked systems consisting of several private and public organizations, by looking at the Dutch railway system. More specifically we analyze a case in which the decision to take several railway tracks and switches out of service resulted in a 
large scale disruption during rush hour in one of the busiest parts of the Netherlands. With the concept of sensemaking we show that the different actors involved were unable to create a common understanding of the situation to enable coordinated action

Keywords: Dutch railway system, sensemaking, coordination, disruption management

\section{Sensemaking in een gefragmenteerd spoorsysteem}

We zijn ons pas bewust van hoe afhankelijk onze samenleving is geworden van grote technische infrastructurele systemen op momenten dat deze het af laten weten. Falen leidt tot grootschalige verstoringen, zoals het uitvallen van de elektriciteitsvoorziening, cyberattacks of de verstoringen in het spoorwegsysteem waarbij duizenden reizigers stranden. De economische en maatschappelijke schade die deze verstoringen veroorzaken is aanzienlijk, nog afgezien van het ongemak dat daarmee voor betrokkenen wordt veroorzaakt. Het is dan ook niet verwonderlijk dat er veel aandacht is om zulke systemen te beschermen tegen verstoringen, dan wel er voor te zorgen dat deze systemen zo snel mogelijk herstellen na een verstoring. Tegelijkertijd wijzen De Bruijne \& Van Eeten (2007) op een op een interessante ontwikkeling: onder invloed van privatisering en verzelfstandiging is de management van deze systemen verschoven van voorheen geïntegreerde hiërarchische organisaties naar complexe netwerken, bestaande uit een groot aantal organisaties met uiteenlopende en soms conflicterende doelen, bevoegdheden en verantwoordelijkheden.

Het Nederlandse spoorwegsysteem is een goed voorbeeld van zo'n netwerk waarbij verschillende private en publieke organisaties (vaak fysiek van elkaar gescheiden) moeten zorgen voor een betrouwbare dienstverlening. Bijna iedereen is wel bekend met de splitsing van de vervoerder NS en infrabeheerder ProRail, maar denk bijvoorbeeld ook aan de vele aannemers die het spoor onderhouden. Deze fragmentatie maakt het systeem complex en vereist voortdurende afstemming van activiteiten en het uitwisselen van informatie. Juist aan deze onderlinge afstemming en de aansturing van verschillende functies wil het nog wel eens schorten, waardoor het moeilijk wordt om verstoringen te voorkomen of deze tijdig op te vangen (Ministerie I\&M, 2011). Daarbij komt dat in een dergelijk complex systeem kleine ongecoördineerde beslissingen uiteindelijk kunnen uitmonden in grote calamiteiten. Dit was ook het geval op 19 februari 2014. Op deze dag werd besloten tot het buitengebruik nemen van 4 wisselcomplexen en twee sporen bij Den Haag en Rotterdam. Wat had moeten resulteren in een beheerste afschaling van de treindienst mondde uiteindelijk uit in een grootscheepse verstoring van het treinverkeer rond Den Haag en Rotterdam. Uiteraard zorgde deze calamiteit voor de nodige media-aandacht en Kamervragen. 
In reactie op de rapporten van TNO en de Inspectie Leefomgeving en Transport (ILT) naar aanleiding van deze calamiteit trokken ProRail en staatssecretaris Mansveld van Infrastructuur en Milieu de conclusie dat een aanscherping en striktere toepassing van procedures noodzakelijk is om de betrouwbaarheid van het spoor te waarborgen (Kamerstuk 29984, nr 471, 6 oktober 2014: Brake, Rypkema \& Schraagen, 2014; ILT, 2014). In dit artikel willen wij, middels een reconstructie van de desbetreffende dag, aantonen dat het ontstaan van stuurloosheid primair terug te voeren is op de spanning tussen formele regels en informele praktijken en niet zozeer het ontbreken van formele regels. Aan de hand van het begrip sensemaking laten we zien dat het niet alleen gaat om de structuren en regels van organisaties, maar vooral over hoe mensen binnen deze organisaties betekenis verlenen aan specifieke situaties (Weick et al., 2005). In deze complexe systemen worden de mensen op de werkvloer immers met onverwachte omstandigheden geconfronteerd, waarbij vooraf gedefinieerde procedures niet altijd voldoen en de betrouwbaarheid van het systeem afhankelijk is van de onderlinge afstemming en beeldvorming (Faraj \& Xiao, 2006).

We zien deze casus als een geval waarin actoren, mede als gevolg van de bovengenoemde fragmentatie, er niet in slaagden tot een gezamenlijke beeldvorming te komen. Dit resulteerde in het stuurloos raken van het proces tot buitengebruikname, terwijl de inzet juist was om de tijd te nemen en de afschaling van de treindienst beheerst te laten verlopen. De vraag daarbij is waardoor men niet tot een gezamenlijk beeld van de situatie kwam. In onze reconstructie gaan we na hoe de betrokkenen betekenis probeerden te verlenen aan de informatie die zij moesten verwerken en welke acties zijn vervolgens ondernamen.

We zullen in de volgende paragraaf eerst een korte beschrijving geven van het Nederlandse spoorsysteem. Vervolgens zullen we het concept sensemaking verder toelichten, waarna de casus wordt gepresenteerd en geanalyseerd.

\section{De complexiteit van het Nederlandse spoorwegsysteem}

ProRail is in Nederland verantwoordelijk voor de aanleg, het onderhoud en de beschikbaarheid van de railinfrastructuur. Ook verzorgt deze publieke taakorganisatie de verkeersleiding: het toedelen van treinpaden aan de vervoerders en het begeleiden van het treinverkeer. ProRail kent 13 regionale verkeersleidingsposten, waarbinnen decentrale verkeersleiders verantwoordelijk zijn voor de optimalisatie van het treinverkeer in de eigen geografisch afgebakende gebieden. Binnen de posten zijn de treindienstleiders eindverantwoordelijk voor de veiligheid van het treinverkeer: zij bewaken 
het veilige verloop van het treinverkeer op specifieke toegewezen secties van het spoor. Dit doen zij voornamelijk door het bedienen van seinen en wissels. De lokale kennis van de posten is zeer belangrijk voor het snel en adequaat kunnen reageren op een verstoring. Daarom kent de verkeersleiding van ProRail een vrij decentraal karakter met aanzienlijke autonomie voor de verschillende posten.

Het kleinschalige onderhoud van het spoor heeft ProRail uitbesteed aan verschillende spooraannemers. Deze spooraannemers zijn elk verantwoordelijk voor het onderhoud van het spoor in één of meerdere gebieden. Om toezicht te houden op de werkzaamheden van de aannemers en de kwaliteit van het spoor te bewaken, heeft ProRail regionale tracé-teams ingesteld. Binnen dit team is de tracémanager verantwoordelijk voor de goede staat van het spoor en daarmee dus de veilige berijdbaarheid. Hij wordt daarbij geholpen door inspecteurs die hem adviseren over te nemen maatregelen bij eventuele afwijkingen. Zij doen dit werk vanuit de verschillende regionale kantoren van ProRail.

Naast een veilige en betrouwbare spoorinfrastructuur speelt de beschikbaarheid van treinen en personeel uiteraard een belangrijke rol in het vervoeren van passagiers. Hier zijn de verschillende vervoerders verantwoordelijk voor. De grootste vervoerder, de NS, heeft voor de bijsturing van materieel en personeel vijf regionale bijsturingscentra (RBC) in Nederland, die ook elk verantwoordelijk zijn voor een specifiek gebied. De samenhang tussen infrastructuur, materieel en personeel resulteert in een complexe puzzel die intensieve afstemming tussen betrokken organisaties vraagt. Door de fysieke afstand tussen de verschillende partijen gaat deze afstemming voornamelijk per telefoon of via een speciaal communicatiesysteem (ISVL). Om de afstand tussen de verschillende partijen letterlijk en figuurlijk te verkleinen is sinds 2010 het Operationeel Controle Centrum Rail (OCCR) in Utrecht in gebruik. Hier zijn de meeste bij het spoor betrokken partijen werkzaam in een gedeelde ruimte om het spoorsysteem op een landelijk niveau te monitoren en daar waar nodig bij te sturen. De komst van het OCCR heeft echter ook gezorgd voor nieuwe coördinatievraagstukken met de regionale posten, die ook in de casusbeschrijving van dit artikel naar voren zullen komen.

Tabel 1: De belangrijkste actoren en hun rolbeschrijving tijdens de buitengebruikname van de wissels en sporen op 19 februari 2014

\begin{tabular}{|l|l|}
\hline Rol & Rol beschrijving \\
\hline Tracé Manager & $\begin{array}{l}\text { Is verantwoordelijk voor de kwaliteit van de spoor infrastructuur en } \\
\text { daarmee de veilige berijdbaarheid }\end{array}$ \\
\hline Inspecteur baan & $\begin{array}{l}\text { Ondersteunt de trace manager in het montitoren van afwijkingen } \\
\text { in de infrastructuur en adviseert over de te nemen maatregelen }\end{array}$ \\
\hline $\begin{array}{l}\text { Decentrale } \\
\text { verkeersleider }\end{array}$ & $\begin{array}{l}\text { Is verantwoordelijk voor de optimalisatie van het treinverkeer in } \\
\text { zijn eigen geografisch afgebakende gebied }\end{array}$ \\
\hline
\end{tabular}




\begin{tabular}{|l|l|}
\hline Treindienstleider & $\begin{array}{l}\text { Is verantwoordelijk voor de veiligheid van het treinverkeer op } \\
\text { specifieke spoorsecties }\end{array}$ \\
\hline $\begin{array}{l}\text { Regisseur } \\
\text { Incidentenregie en } \\
\text { infrabeheer (RIIB) }\end{array}$ & $\begin{array}{l}\text { Is het aanspreekpunt in het OCCR ten aanzien van de afhandeling } \\
\text { van incidenten en herstel van infrastructuur. }\end{array}$ \\
\hline $\begin{array}{l}\text { Regisseur Landelijke } \\
\text { Verkeersleiding (RLVL) }\end{array}$ & Aanspreekpunt in het OCCR van de landelijke verkeersleiding \\
\hline $\begin{array}{l}\text { Schakel- en } \\
\text { meldcentrum (SMC) }\end{array}$ & $\begin{array}{l}\text { Naast het bedienen van de bovenleidingspanning, noteert het SMC } \\
\text { meldingen van infrastoringen en geeft deze door aan de aannemer. }\end{array}$ \\
\hline $\begin{array}{l}\text { Regisseur Landelijke } \\
\text { Bijsturing (RLBC) }\end{array}$ & $\begin{array}{l}\text { Is namens de NS het aanspreekpunt in het OCCR van de landelijke } \\
\text { bijsturing }\end{array}$ \\
\hline
\end{tabular}

\section{De rol van sensemaking tijdens coördinatie in complexe systemen}

Actoren in complexe systemen worden veelvuldig geconfronteerd met onverwachte gebeurtenissen, waarbij ze niet altijd kunnen terugvallen op vooraf gedefinieerde regels en procedures. In zo'n geval dienen de betrokken actoren wederzijdse afstemming te vinden en gezamenlijk te improviseren. Een afgestemd beeld van de situatie is daarbij belangrijk want deze maakt duidelijk wat van hen verwacht wordt en hoe de verschillende activiteiten zich tot elkaar verhouden (Cornelissen et al., 2014). Onderlinge communicatie speelt daarin een cruciale rol (Faraj \& Xiao, 2006). Het delen van informatie is echter geen gemakkelijk opgave. Niet alleen is er het probleem dat de uitwisseling tussen verschillende organisaties vaak moeilijk gaat (Pidgeon \& O'leary, 2000), maar uit studies blijkt ook dat de fysieke afstand tussen partijen er voor zorgt dat informatie niet evenredig, tijdig en volledig wordt gedeeld (Hinds \& Pamela, 2006). Daar komt bij dat de partijen vanuit verschillende contexten en belangen werken, waardoor informatie anders geïnterpreteerd kan worden dan oorspronkelijk bedoeld.

In het management van onverwachte gebeurtenissen speelt sensemaking een belangrijke rol. Dit vindt plaats doordat actoren 'cues' onderkennen die hen erop wijzen dat zij met een afwijkende situatie te maken hebben, hetgeen onzekerheid creeert. Vervolgens proberen zij betekenis aan deze cues te geven, door deze te verbinden met een cognitief frame, oftewel het categoriseren van de cue, die interpretatie en handelen stuurt (Maitlis, 2005; Maitlis \& Christianson, 2014; Sandberg \& Tsoukas, 2014; Weick, Sutcliffe, \& Obstfeld, 2005). Sensemaking helpt actoren dus om te gaan met onzekerheid en ambiguïteit door een plausibele interpretatie van de situatie te creëren die als leidraad dient voor verdere acties om de verstoorde situatie te herstellen. Veelal zullen actoren op zoek gaan naar frames die het mogelijk maken om de bestaande activiteit te hervatten en pas later op zoek gaan naar een alternatieve aanpak (Weick et al. 2005). Er is dus een spanning waarneembaar tussen de wens om situaties te herstellen volgens de voorgeschreven procedures en regels en de noodzaak om flexibel te 
blijven om snel in te kunnen spelen op gewijzigde omstandigheden (Maitlis \& Sonenshein, 2010; Murphy, 2001).

Sensemaking is bovenal een sociaal proces, aangezien de interpretatie van specifieke situaties tot stand komt tijdens interacties (Maitlis, 2005). In termen van coördinatie is het belangrijk om een gedeeld beeld van de situatie te verkrijgen zodat afgestemd handelen mogelijk wordt. In hoeverre men daar in slaagt, is afhankelijk van hoe men individueel en collectief situaties interpreteert en herinterpreteert (Cornelissen et al., 2014). Het creëren van een gedeeld begrip is echter geen gemakkelijke taak, zeker niet in het geval van actoren met verschillende (institutionele) achtergronden. Dit vergt veel inspanning en de nodige communicatie (Bechky, 2003). Betrokkenen hoeven uiteindelijk niet een volledig overeenstemmende interpretatie te hebben, maar het beeld dat elk van hen hanteert dient voldoende afgestemd te zijn met dat van de anderen, zodat een betekenisvolle en door alle betrokken begrepen actie kan worden ondernomen.

In de volgende sectie zullen we de casus beschrijven, waarbij sensemaking onze leidraad is in het interpreteren van de communicatie. Sensemaking omvat daarbij de stappen informatieverzameling, betekenisverlening (framing) en actie. Het hele proces van sensemaking is opgedeeld in drie rondes, of zoals ze in de sensemaking literatuur vaak worden geduid: episodes. Deze indeling is tot stand gekomen door te kijken naar veranderingen in de interacties tussen actoren, belangrijke gebeurtenissen en besluiten. Aan de hand van drie episodes wordt er gekeken hoe informatie over de buitengebruikname wordt gedeeld, hoe actoren deze informatie interpreteren en welke actie zij daaraan verbinden. Daarbij vormen de besluiten uit de eerste episode de input voor de daaropvolgende episodes. De systematische reconstructie van de buitengebruikname van de wissels en sporen is gedaan op basis van opnames van telefoongesprekken die de verschillende functionarissen op de dag van de verstoring met elkaar voerden en die vervolgens zijn getranscribeerd. In aanvulling daarop voerden we negen interviews met de belangrijkste betrokkenen en kregen we inzage in de logs, shift reports en het e-mailverkeer. Een uitgebreide beschrijving van alle databronnen, de begrenzing van de episodes en gehanteerde methoden is te vinden in (Schipper \& Gerrits, 2015).

\section{De buitengebruikname van wissels en sporen op 19 februari 2014}

De $19^{e}$ februari begint met de ontdekking van afwijkingen in de veiligheidswaardes bij twee sporen op Den Haag Centraal Station door een inspectieploeg van een spooraannemer. Dit betekent niet dat er 
direct sprake is van een onveilige situatie, maar wel dat nadere inspectie noodzakelijk is. De spooraannemer bespreekt diezelfde ochtend de resultaten van de nachtelijke inspectie met de inspecteur baan van ProRail. Deze was op dat moment ook bezig met de maandelijkse rapportages van vier wissels (twee in Den Haag en twee in Rotterdam) die ook te kampen hadden met overschrijdingen in de veiligheidswaarden. Deze vier wissels werden maandelijkse visueel geïnspecteerd om de veilige berijdbaarheid te kunnen garanderen in afwachting van verder herstel. De inspecteur baan gaat in overleg met de tracé manager over de problematiek met de wissels en sporen en gezamenlijk komen zij tot de conclusie geen vertrouwen te hebben in een herstel van de wissels en sporen. Zij besluiten daarom, rond het middaguur, de wissels en sporen buitengebruik te laten nemen, zodat deze later vervangen kunnen worden.

De keuze om zo kordaat in te grijpen bij deze wissels en sporen heeft te maken met eerdere ontwikkelingen. Bij één van de wissels is vernieuwing meerdere malen uitgesteld vanwege een gebrek aan financiële middelen. Hierdoor begon het regionale tracé-team steeds meer af te wijken van de eigen normen en moesten zij steeds meer op hun eigen expertise vertrouwen in de beoordeling van de veilige berijdbaarheid van de infrastructuur. Een omslag in het denken van het tracé-team volgt door audits van de Inspectie Leefomgeving en Transport. Zij benadrukken dat het tracé-team de eigen regels niet naleeft en verantwoordelijk is voor eventuele gevolgen. Het tracé-team besluit daarop de normen strak te gaan hanteren. Zij zijn zich echter ook bewust van de impact van hun besluit op de treindienst en de vele partijen aan wie zij verantwoording af zullen moeten leggen. Daarom wordt het besluit genomen om de buitengebruikname van de wissels en sporen tot zes uur's avonds uit te stellen, zodat de verschillende partijen tijdig geïnformeerd kunnen worden en de nodige voorbereidingen kunnen treffen om de treindienst gecontroleerd af te kunnen schalen.

\section{Episode 1: 15:15 tot 16:00}

Vanuit die gedachte neemt de tracémanager rond kwart over drie contact op met de regisseur incidentenregie en infrabeheer (RIIB) in het OCCR. De tracémanager vertelt de RIIB dat zij voorbereidingen aan het treffen zijn voor een aantal 'rode vlaggen' bij Den Haag. De klassieke rode vlag staat symbool in de spoorwereld voor het buitengebruik nemen van een stuk spoor vanuit het oogpunt van veiligheid. De tracé manager benadrukt daarbij dat deze keuze gemaakt is op basis van overschrijdingen van veiligheidswaardes en zij zodoende wel hun verantwoordelijkheid moeten nemen. De RIIB betwist het besluit van het tracé-team niet en geeft aan 'in control' te willen blijven, maar daarom wel meer informatie nodig te hebben over de wissels en het exacte tijdstip van de onttrekking. De tracémanager belooft deze aan te leveren. De RIIB deelt de eerste (incomplete) 
informatie direct met zijn collega regisseurs van NS en de verkeersleiding (RLVL) om de rode vlag situatie gezamenlijk op te pakken.

De regisseur van NS en de verkeersleiding besluiten allebei iets compleet anders te doen met deze informatie. De regisseur van NS zit op dat moment in een conference-call met de shiftleaders van de regionale bijsturingscentra ( $R B C$ ) en deelt met hen deze eerste signalen over de aanstaande rode vlaggen in Den Haag. De RLVL besluit daarentegen om nog geen contact te zoeken met de treindienstleiders op de verkeersleidingspost van Den Haag in afwachting van verdere details. De informatie over de rode vlaggen komt uiteindelijk toch bij de treindienstleiders terecht, als het RBC contact op neemt met de verkeersleidingspost Den Haag om de geruchten over de rode vlaggen bevestigd te krijgen. De verbaasde post neemt daarop contact op met de RLVL en benadrukt dat de treindienstleiders als eerste geïnformeerd dienen te worden in het geval een rode vlag, aangezien het om een veiligheidskwestie gaat. De RLVL ondersteunt deze zienswijze en geeft aan dat normale procedures verder gevolgd zullen worden.

Tabel 2. Informatieuitwisseling, sensemaking en acties gedurende episode 1

\begin{tabular}{|c|c|c|}
\hline $\begin{array}{l}\text { Belangrijke } \\
\text { actoren }\end{array}$ & Sensemaking & Actie \\
\hline Tracé manager & $\begin{array}{l}\text { Op basis van overschrijdingen in de } \\
\text { veiligheidswaardes moest het tracé team } \\
\text { zijn verantwoordelijkheid nemen en de } \\
\text { rode vlag in het spoor steken. Gezien de } \\
\text { impact van dit besluit is een goede } \\
\text { voorbereiding noodzakelijk om de } \\
\text { treindienst gecontroleerd af te schalen } \\
\text { en daarom moet het OCCR het proces } \\
\text { coördineren. }\end{array}$ & $\begin{array}{l}\text { Het OCCR voorzien van een eerste waarschuwing, } \\
\text { zodat zij het proces kunnen coördineren en de } \\
\text { treindienstleider kunnen informeren }\end{array}$ \\
\hline RIIB & $\begin{array}{l}\text { Deze rode vlag situatie moet gezamenlijk } \\
\text { en in controle worden opgepakt. }\end{array}$ & $\begin{array}{l}\text { Delen van de eerste informatie met de RLVL en de } \\
\text { RLBC }\end{array}$ \\
\hline RLVL & $\begin{array}{l}\text { 1. Er is nog te weinig bekend om de } \\
\text { treindienstleiders op de hoogte te } \\
\text { brengen van de situatie. } \\
\text { 2. In een rode vlag situatie moet, zoals } \\
\text { de procedures voorschrijven, het } \\
\text { proces beginnen bij de } \\
\text { treindienstleiders. }\end{array}$ & $\begin{array}{l}\text { 1. Informeert eerst met de team leider van de } \\
\text { verkeersleidingspost van Den Haag } \\
\text { 2. Spoort de RIIB aan om de treindienstleiders } \\
\text { officieel te informeren over de situatie. }\end{array}$ \\
\hline RLBC & $\begin{array}{l}\text { De mogelijke rode vlag situatie kan van } \\
\text { invloed zijn op de treindienst }\end{array}$ & Direct informeren van de RBC's. \\
\hline
\end{tabular}

Episode 2: 16:00 tot 17:10 
Rond 16:00 ontvangt de RIIB de volledige details over de buitengebruikname van de wissels en sporen van de tracé manager. Hij deelt deze informatie vervolgens met de andere regisseurs tijdens hun reguliere overleg. Direct hierna ontstaat weer een geruchtenstroom als de vervoerders contact beginnen op te nemen met de verkeersleidingsposten van Den Haag en Rotterdam om de situatie van de rode vlaggen met hen te bespreken. Beide posten zijn op dat moment echter nog altijd niet officieel geïnformeerd en krijgen door de vele geruchten steeds meer het gevoel dat zij buiten gesloten worden en dat anderen veel meer informatie tot hun beschikking hebben. Dit laatste klopt ook want de volledige informatie was beschikbaar bij de landelijke verkeersleiding maar zij waren nog altijd overtuigd dat de treindienstleiders via de officiële kanalen (SMC, aannemer) geïnformeerd zouden worden. Om verdere verwarring te vermijden, besluiten zij daarom ook maar om tijdelijk geen contact te zoeken met de posten.

Rond half vijf neemt de inspecteur baan contact op met het Schakel en Meldcentrum (SMC) om de formele procedure voor de buitengebruikname van de wissels en sporen op te starten. Het SMC maakt daarbij een rapport aan met een specifiek nummer die gebruikt wordt in de communicatie tussen de treindienstleider en spooraannemer. In het gesprek met het SMC geeft de inspecteur baan aan reeds contact te hebben gehad met het OCCR en die zouden de treindienstleiders al hebben geïnformeerd. Zodoende zou het SMC geen partij zijn in het informeren van de treindienstleiders. In het OCCR was men juist in afwachting van het officiële bericht van het SMC aan de treindienstleiders. Deze verwarring duurt tot tien over vijf, waarna de RIIB het tracé team vraagt om contact op te nemen met beide posten.

Tabel 3. Informatieuitwisseling, sensemaking en acties gedurende episode 2

\begin{tabular}{|c|c|c|}
\hline $\begin{array}{l}\text { Belangrijke } \\
\text { actoren }\end{array}$ & Sensemaking & Actie \\
\hline RLVL & $\begin{array}{l}\text { De RLVL is er van overtuigd dat zij tot het } \\
\text { moment dat de treindienstleiders } \\
\text { geïnformeerd zijn geen rol in het proces } \\
\text { hebben }\end{array}$ & $\begin{array}{l}\text { Besluit om tijdelijk geen contact te zoeken met de } \\
\text { posten om verdere verwarring te voorkomen }\end{array}$ \\
\hline $\begin{array}{l}\text { SMC/Inspecteur } \\
\text { baan }\end{array}$ & $\begin{array}{l}\text { De inspecteur baan meldt dat het tracé- } \\
\text { team al contact heeft opgenomen met } \\
\text { het OCCR en dat daarmee het proces } \\
\text { reeds loopt bij verkeersleiding. }\end{array}$ & Neemt geen contact op met de treindienstleiders \\
\hline Treindienstleiders & $\begin{array}{l}\text { Krijgen het gevoel dat zij buiten gesloten } \\
\text { worden van het proces en dat anderen } \\
\text { over veel meer informatie beschikken. } \\
\text { Door het gebrek aan informatie kunnen } \\
\text { zij niet in hun rol komen om de veiligheid } \\
\text { van de treindienst te bewaken. }\end{array}$ & $\begin{array}{l}\text { Gaan op zoek naar bevestiging van de geruchten } \\
\text { over de wissels en beschuldigen de landelijke } \\
\text { verkeersleiding van het niet volgen van de } \\
\text { procedures. }\end{array}$ \\
\hline
\end{tabular}


De inspecteur baan belt rond half zes eerst met de post Den Haag en geeft aan welke wissels en sporen niet meer gebruikt mogen worden na zes uur. De treindienstleider weigert echter mee te werken, aangezien niet de juiste procedures worden gevolgd en adviseert de inspecteur baan contact op te nemen met de team leider van de post. Een paar minuten later belt de inspecteur baan ook met de treindienstleider Rotterdam. Deze besluit direct de wissels buitengebruik te nemen.

Opvallend daarbij zijn de verschillen tussen de interpretaties van de situatie door de treindienstleiders in Den Haag en Rotterdam. In Den Haag had men het gevoel dat er geen sprake kon zijn van een onveilige situatie, want zij hadden immers al uren over de wissels en sporen gereden terwijl de geruchten over een rode vlag rond gingen. Zij besluiten dan ook vast te houden aan de procedures en door te blijven rijden totdat iemand via de officiële weg hen vertelt dat de situatie daadwerkelijk onveilig is. Bovendien werd het verlenen van medewerking aan de inspecteur baan gezien als een aantasting van de eigen positie. De kans bestaat dan immers dat medewerking gezien wordt als vrijbrief om vaker deze onofficiële procedures te volgen en anderen te laten beslissen over veiligheidskwesties. De treindienstleider in Rotterdam, echter, zag de inspecteur baan als iemand die hem vertelde over een onveilige situatie in zijn werkgebied en besloot zodoende direct over te gaan tot actie in plaats van te wachten tot zes uur. In beide gevallen volgen de treindienstleiders dus niet de instructies van de inspecteur baan op.

Tabel 4. Informatieuitwisseling, sensemaking en acties gedurende episode 3

\begin{tabular}{|l|l|l|}
\hline $\begin{array}{l}\text { Belangrijke } \\
\text { actoren }\end{array}$ & Sensemaking & Actie \\
\hline $\begin{array}{l}\text { Dreindienstleider } \\
\text { Den Haag }\end{array}$ & $\begin{array}{l}\text { Er lijkt geen sprake te zijn van direct } \\
\text { gevaar. Medewerking verlenen aan de } \\
\text { inspecteur baan is een vrijbrief voor } \\
\text { het tracé-team om vaker dit soort } \\
\text { besluiten te nemen en procedures te } \\
\text { volgen. }\end{array}$ & $\begin{array}{l}\text { De inspecteur baan wordt niet erkend als een } \\
\text { deskundige en zijn informatie wordt verworpen. } \\
\text { De treindienstleiders blijven voorlopig gebruik } \\
\text { maken van de wissels en sporen. }\end{array}$ \\
\hline $\begin{array}{l}\text { Treindienstleider } \\
\text { Rotterdam }\end{array}$ & $\begin{array}{l}\text { De treindienstleider ziet in het bericht } \\
\text { van de inspecteur baan een } \\
\text { onmiddellijk gevaar voor de veilige } \\
\text { berijdbaarheid van de infrastructuur in } \\
\text { zijngebied. }\end{array}$ & $\begin{array}{l}\text { De treindeinstleider neemt direct de wissels } \\
\text { buitengebruik. }\end{array}$ \\
\hline
\end{tabular}

Om tien voor zes neemt een aannemer contact op met een treindienstleider in Den Haag. Deze wil de treindienstleiders op de hoogte brengen van de informatie die hij tot zijn beschikking heeft en noemt de wissels die buitengebruik genomen moeten worden. Hij geeft echter ook aan te wachten op 
verdere details. Op dat moment nadert een lege trein één van de genoemde wissels en de treindienstleider besluit deze een noodstop te laten maken, aangezien de monteur niet kan aangeven of deze veilig is of niet. In reactie op de noodstop besluiten de treindienstleiders het treinverkeer rond Den Haag Centraal Station en Hollands Spoor geheel stil te leggen tot er meer duidelijkheid is over de veilige berijdbaarheid van de wissels en sporen. Uiteindelijk duurt het bijna een uur totdat de treindienstleiders de beschikking krijgen over de juiste informatie afkomstig van de spooraannemer en men de treindienst weer kan gaan opstarten. Opvallend genoeg worden diezelfde nacht drie van de vier wissels zonder vervanging weer in gebruik genomen op basis van normen die op 1 april 2014 van kracht zouden worden (IL\&T, 2014).

\section{Hoe men niet tot een gezamenlijke beeldvorming kwam}

De drie episodes hebben laten zien dat betrokken er niet in slaagden een gezamenlijk beeld te ontwikkelen van de situatie om tot een gecoördineerde aanpak te komen, met als gevolg misverstanden, het niet doorkomen van informatie, oplopende irritaties over geruchten en het gevoel buitenspel gezet te worden. Het gevolg is het plotseling staken van het treinverkeer, terwijl oorspronkelijk ruimte bestond om de wissels op gecontroleerde wijze buiten gebruik te nemen en vooraf de treindienst af te schalen. Welke factoren voorkomen de totstandkoming van een gemeenschappelijk beeld? In de casusbeschrijving vallen de volgende zaken op.

Formele procedures versus informele handelingen. De keuze van het tracé-team om de buitengebruikname van de wissels en sporen uit te stellen tot zes uur en het proces door het OCCR te laten coördineren, zorgde voor een onduidelijke situatie voor de andere partijen in het spoorsysteem. Zo impliceert een rode vlag een direct gevaar, aangezien de veilige berijdbaarheid van een wissel of spoor niet meer gegarandeerd kan worden. Dit komt niet overeen met het hanteren van een voorwaarschuwing en de uitstel tot zes uur 's avonds. Bovendien is een voorwaarschuwing, hoewel attent, geen officiële procedure in de spoorsector. Formeel zou bij een rode vlag situatie direct gecommuniceerd moeten worden met de treindienstleiders, aangezien zij verantwoordelijk zijn voor de veiligheid van het treinverkeer. Nadien moet de verkeersleidingspost het OCCR informeren over de te volgen procedure. In de casus is goed te zien dat de informele aanpak van het tracé-team conflicteert met de interpretatie van de situatie door het OCCR, als zijnde een standaard procedure. In plaats van een effectieve communicatie tussen het OCCR en de posten over een geïmproviseerde aanpak, was men vooral druk bezig met het herstellen van bestaande procedures en werd communicatie geminimaliseerd om verdere verwarring te voorkomen. Tegelijkertijd waren de tracé- 
manager en inspecteur baan nog steeds in de veronderstelling dat de treindienstleiders reeds geïnformeerd waren. Hierdoor bleef een officieel bericht richting de treindienstleiders lang uit.

Kennis van elkaars werkprocessen en denkwijzen. De betrokkenen zijn goed getraind in het volgen van hun eigen werkprocessen. Echter, de kennis over de werkprocessen van actoren uit andere organisaties is veel minder bekend. Bijvoorbeeld, ten aanzien van de vraag wie als eerste geïnformeerd moet worden, blijkt er geen eenduidig beeld te bestaan. De casus heeft laten zien dat het tracé-team onvoldoende het belang inzag van een directe dialoog met de treindienstleiders over het door hen genomen besluit. Juist met de treindienstleiders moest echter een verschil in perceptie over veiligheid overbrugd worden. Waar het tracé-team op basis van hun expertise een uitstel van de buitengebruikname van de wissels en sporen verantwoord vond, is voor een treindienstleider een rode vlag situatie met uitstel moeilijk te begrijpen. Vanuit hun rol bezien geldt immers dat iets ofwel veilig, ofwel onveilig is. Voor een treindienstleider bestaan daar geen gradaties in. Dit verschil in perceptie kon zo vlak voor de deadline niet meer overbrugd worden.

Het ontstaan van onzekerheid. Het uitblijven van een officieel bericht en het aanhouden van de geruchten over de rode vlaggen zorgden voor onzekerheid bij de treindienstleiders. Zij wisten dat er problemen waren met de veilige berijdbaarheid van wissels en sporen, maar niet om welke wissels en sporen het precies ging. Hierdoor konden zij hun rol niet vervullen in het bewaken van een veilige treindienst. Op zo'n moment speelt sensemaking een belangrijke rol in het bepalen van de te nemen acties. Waar de treindienstleiders in Den Haag er voor kiezen om strikt de procedures te volgen, besluit de treindienstleider in Rotterdam te improviseren en direct de wissels buitengebruik te nemen. Anders gezegd: de ontstane onzekerheid blijkt ruimte te geven om twee heel verschillende wegen te bewandelen. Zowel de treindienstleiders in Den Haag als Rotterdam wijken echter af van het plan van het tracé-team om de wissels en sporen om zes uur buitengebruik te nemen.

Samenvattend: de gezamenlijke beeldvorming blijft uit omdat de eigen procedures en doelstellingen weliswaar helder zijn, maar op veel vlakken niet goed aansluiten bij de procedures en doelstellingen van andere betrokkenen in het netwerk. Daarbij is het de verschillende partijen niet gelukt om, weliswaar onder tijdsdruk, deze knelpunten weg te nemen om tot een alternatieve gezamenlijke aanpak te komen.

\section{Conclusie en reflectie}

De conclusies van ProRail en de staatssecretaris dat een aanscherping en striktere toepassing van procedures noodzakelijk is om de betrouwbaarheid van het spoor te waarborgen, is ogenschijnlijk gerechtvaardigd gezien de vele afwijkingen van de procedures op 19 februari 2014. Tegelijkertijd lijkt 
het een illusie dat afwijkingen van regels en procedures voorkomen kunnen worden in een complex systeem, zoals die van het Nederlandse spoor. Deze afwijkingen kunnen bovendien condities creëren die uiteindelijk tot onverwachte en ambigue situaties leiden, zoals die beschreven in de casus, welke vaak niet binnen de standaard procedures en regels vallen (Goodman et al., 2011). Naast het voorkomen van afwijkingen, benadrukken wij dan ook het belang van het tijdig kunnen reageren op een onverwachte situatie en het gezamenlijk kunnen improviseren in plaats van exclusief te blijven werken middels een eigen logica. De casus heeft echter laten zien dat dit geen gemakkelijke opgave is.

Zoals Weick (2005) aangeeft is er vooral in netwerken van organisaties een neiging bij actoren tot normalisatie, i.e. het vasthouden aan routinematig gedrag bij niet-routinematige problemen. Procedures bieden namelijk houvast voor de verschillende actoren in het omgaan met onzekerheid, maar kunnen ook de noodzaak voor improvisatie verhullen. Als er geen gezamenlijk beeld ontstaat tussen betrokkenen zullen zij verschillende, mogelijk conflicterende, strategieën volgen, waarbij men tevens verkeerde aannames doet over de interpretatie van de situatie door anderen. De casus laat daarbij zien dat het voor partijen die fysiek van elkaar gescheiden zijn moeilijk is om coördinatieproblemen snel te herkennen en daar op te acteren. Daarnaast leidt de onderlinge afstand al snel tot onderlinge verwijten als informatie niet tijdig wordt gedeeld en kan dit zelfs uitmonden in een onderling conflict.

De fysieke afstand tussen de organisaties in de spoorsector en de verschillende contexten waarin zij werken, vraagt dan ook om sterke relaties tussen de verschillende partijen (Gittel, 2011). Dit geldt uiteraard niet alleen voor de relaties tussen organisaties, of die tussen het OCCR en de regio, maar bovenal ook die tussen de verschillende organisatieonderdelen. Een goed begrip van de elkaars processen draagt bij aan een effectieve communicatie en onderling vertrouwen zet mensen aan om de juiste kritische vragen te stellen en daar waar nodig anderen op een positieve manier te corrigeren, zodat er een gezamenlijke beeld behouden blijft (Weick, 1993; 2005). Dit maakt het systeem in zijn geheel beter in staat om tijdig en adequaat te kunnen reageren op onverwachte problemen. 


\section{Referenties}

Bechky, B. A. (2003). Sharing meaning across occupational communities: The transformation of understanding on a production floor. Organization Science, 14(3), 312-330.

Brake, G.M., te, Rypkema, J.A. \& J.M.C. Schraagen (2014). Evaluatierapport betreffende de buitengebruikname van wissels en sporen bij Den Haag en Rotterdam op 19 februari 2014. Soesterberg: TNO.

Cornelissen, J. P., Mantere, S., \& Vaara, E. (2014). The contraction of meaning: The combined effect of communication, emotions, and materiality on sensemaking in the stockwell shooting. Journal of Management Studies. In press.

De Bruijne, M., \& Van Eeten, M. (2007). Systems that should have failed: Critical infrastructure protection in an institutionally fragmented environment. Journal of Contingencies and Crisis Management, 15(1), 18-29.

Faraj, S., \& Xiao, Y. (2006). Coordination in fast-response organizations. Management Science, 52(8), 1155-1169.

Gittell, J. H. (2011). New directions for relational coordination theory. In S. Kim C., \& R. Spreitzer (Eds.), Oxford handbook of positive organizational scholarship (pp. 400-411). Oxford: Oxford University Press. 
Goodman, P. S., Ramanujam, R., Carroll, J. S., Edmondson, A. C., Hofmann, D. A., \& Sutcliffe, K. M. (2011). Organizational errors: Directions for future research. Research in Organizational Behavior, 31, 151-176.

IL\&T (2014). Onderzoek naar het buiten gebruik nemen van wissels en sporen in Den Haag en Rotterdam op 19 februari 2014. Den Haag: IL\&T.

Maitlis, S. (2005). The social processes of organizational sensemaking. Academy of Management Journal, 48(1), 21-49.

Maitlis, S., \& Christianson, M. (2014). Sensemaking in organizations: Taking stock and moving forward. The Academy of Management Annals, 8(1), 57-125.

Maitlis, S., \& Sonenshein, S. (2010). Sensemaking in crisis and change: Inspiration and insights from weick (1988). Journal of Management Studies, 47(3), 551-580.

Ministerie van Infrastructuur en Milieu. (2011). Functioneren spoor. The Hague: Ministerie I\&M.

Murphy, A. (2001). The flight attendant dilemma: An analysis of communication and sensemaking during in-flight emergencies. Journal of Applied Communication Research, 29(1), 30-53.

Pidgeon, N., \& O'Leary, M. (2000). Man-made disasters: Why technology and organizations (sometimes) fail. Safety Science, 34(1), 15-30.

Sandberg, J., \& Tsoukas, H. (2014). Making sense of the sensemaking perspective: Its constituents, limitations, and opportunities for further development. Journal of Organizational Behavior, In press.

Schipper, D. \& L. Gerrits (2015). Coordination under uncertainty and time pressure between distributed teams: Communication and sensemaking in the Dutch railway system. IRSPM Conference: Birmingham (2015, maart 30 - 2015, april 01).

Weick, K. E. (1993). The collapse of sensemaking in organizations: The mann gulch disaster. Administrative Science Quarterly, 628-652.

Weick, K. E., Sutcliffe, K. M., \& Obstfeld, D. (2005). Organizing and the process of sensemaking. Organization Science, 16(4), 409-421. 
i Dit onderzoek is uitgevoerd binnen het ExploRail onderzoeksprogramma, met als thema Whole System Performance. Het onderzoek maakt deel uit van het project Managing Complex System Disruptions (MaCSyD) en wordt gefinancierd door NWO, STW en ProRail 